\title{
RELATIVE EFFICIENCY OF SOME COTTON GENOTYPES FOR SEED COTTON YIELD AND ITS COMPONENTS UNDER LATE PLANTING

\author{
Ali, A. A. ${ }^{*}$, Ola A. Galal ${ }^{*}$, M. E. Abd El-Salam ${ }^{\star *}$ and F. E. Elfeki ** \\ * Genetics Dept., Fac. of Agric., Kafrelsheikh Univ., Kafr El-Sheikh, \\ Egypt. \\ ** Cotton Research Institute, Agricultural Research Center, Giza, Egypt.
}

\begin{abstract}
Sowing date plays an important role in the performance of the Egyptian cotton. So cotton breeders in Egypt pay a great attention to develop new cultivars adapted to late sowing date with a good yield. This study was aimed to select some adapted genotypes for sowing under late planting date which enable the producers to grow some winter crops before cotton planting date. One cycle of pedigree selection for early cotton traits; boll weight, seed cotton yield, lint of seeds per boll and early index was completed in conventional late analysis in two $F_{3}$ populations of Egyptian cotton. Two experiments were conducted, the first in conventional (May) and the second in late sowing (June) of 80 families from population I and 78 families from population II were planted in both sowing dates (May and June) in Randomized Complete Block Design (RCBD) of three replications in 2013 cotton growing season. As well as $F_{2}$ single plants from both populations were planted under late sowing date in 2012 cotton growing season. The results of $F_{2}$ population I showed that the genotypic co-efficient of variation of seed cotton yield per plant was higher in the late sowing date (32.52) than the conventional sowing date of $F_{3}$ population I (16.29). While, it was lower than that of late sowing date of $F_{3}$ population I (34.74). The genotypic coefficient of variation of seed cotton yield per plant was higher (33.34) under late sowing date of $\mathrm{F}_{2}$ population II than both conventional and late sowing date of $F_{3}$ population II (17.30 and 13.99), respectively. Heritability estimates in broad sense were high in both conventional and late sowing date of $\mathrm{F}_{3}$ population I and II $(74.85-77.84 \%)$ and $(74.06-53.98 \%)$, respectively. While, heritability estimates in broad sense were 47.84 and $45.60 \%$ in both $F_{2}$ populations under the late planting date, respectively. Seed cotton yield per plant of population I ranged from 24.78 to $56.79 \mathrm{~g}$ under conventional sowing date and from 15.29 to $68.55 \mathrm{~g}$ under the late sowing date. While, it ranged in population II from 33.4 to $59.50 \mathrm{~g}$ and from 33.20 to $62.25 \mathrm{~g}$ under conventional and late planting date, respectively. The observed gain in population I for seed cotton yield per plant as percentage from better parent in conventional sowing date ranged from 7.01 to $20.10 \%$ and from 28.70 to $66.50 \%$ in late sowing date. While, it ranged from 19.60 to $34.30 \%$ and from 63.20 to $111.10 \%$ in the conventional and the late sowing dates for the commercial variety (Giza86), respectively. The observed gain in population II as percentage from better parent in conventional and late sowing dates ranged from 9.0 to $17.6 \%$ and from 42.9 to $51.10 \%$, respectively. While, it ranged from 30.40 to $40.70 \%$ and from 81.20 to $91.50 \%$ compared with the commercial variety, respectively of the same population.
\end{abstract}

\section{INTRODUCTION}

Sowing date plays an important role in the performance of the Egyptian cotton. Stable performance of varieties under different environment with regard to economic characters like seed and lint yields is one of the focal 
endeavors of the Egyptian cotton (Gossypium barbadense L.) breeding programs. Cotton breeders in Egypt pay a great attention to develop new cultivars adapted to late sowing date with a good yield. This will enable the producers to grow early winter crops before cotton planting date. Late sowing in first of June has an adverse effect on yield and yield component traits. Burton (1952) suggested that genotypic coefficient of variation together with heritability would give the best indication of the amount of genetic variance to be expected from selection. Mahdy (1983 a and $b$ ) indicated that the modified selection index was more efficient in improving lint yield and its component traits than conventional index and single trait selection. The author noted that the lint yield was increased with 6.5 to $8.4 \%$ in the two populations under study after two cycles of pedigree selection. Singh et al., (1985) indicated that pedigree selection was better than progeny bulk selection in improving yield. Awaad and Hassan (1996) used direct selection for seed cotton yield in the $F_{2}$ and $F_{4}$ of six Egyptian cotton crosses and found that selection for seed cotton yield was effective in only three crosses. Singh et al., (1993 and 1995) used pedigree selection and selection index to improve seed cotton yield. Mahdy et al., (2001) reported that recurrent selection for seed cotton yield per plant was better than pedigree selection in early and late sowing date of two populations of Egyptian cotton. Mahdy et al., (2007) reported that selection for seed cotton yield per plant caused adverse effects on earliness and resulted in late mature families. Gamal et al., (2009) studied the genetic behavior of some local cotton genotypes under adverse environmental conditions. The heritability estimates differed from favorable and stress 0.32 $0.78 ; 0.69-0.82$ and $0.19-0.8$ for seed cotton yield/plant, lint percentage and boll weight, respectively. Iqbal and khan (2011) studied the effects of five planting dates (May 1, May 15, May 30, June 15 and June 30), plant spacing and genotypes on seed cotton yield and its component traits and then reported that number of bolls per plant and seed cotton yield differed significantly among different planting dates, plant spacing and genotypes. While, the boll weight was differed significantly among genotypes only.

The present work aimed to improve seed cotton yield and its component traits at conventional and late sowing dates for two Egyptian populations using pedigree selection.

\section{MATERIALS AND METHODS}

This study was carried out at the Genetics Dept, Fac. of Agric. Kafr elsheikh university and the farm of cotton Maintenance Research Section at Sakha Agricultural Research Station, Agriculture Research Center, Egypt. during 2012 and 2013 cotton growing seasons.

Two populations of cotton were used in this study. Population I was stemmed from the cross between Giza86×10229 and PimaS6×Giza89, while population II was derived from the cross between Giza75×Sea Island and Australian13. Data in Table 1 showed the pedigree, origin and main characters for the seven parents involved of the two studied populations. 
Table 1: Pedigree, origin and main characters of parental cotton genotypes.

\begin{tabular}{|c|c|c|c|}
\hline Genotypes & Pedigree & Origin & Main characters \\
\hline \multirow{2}{*}{ Giza86×10229 } & 10229 & Australia & \multirow{2}{*}{$\begin{array}{l}\text { New developed elite cotton line, } \\
\text { characterized by high yield and earliness. }\end{array}$} \\
\hline & Giza86 & Egypt & \\
\hline \multirow{2}{*}{ PimaS6×Giza89 } & Giza89 & Egypt & \multirow{2}{*}{ High yield and more earliness. } \\
\hline & PimaS6 & America & \\
\hline \multirow{2}{*}{ Giza75×Sea Island } & Giza75 & Egypt & \multirow{2}{*}{ Compact long stable, high yield and strong lint. } \\
\hline & Sea Island & America & \\
\hline Australian13 & Australian13 & Australian & $\begin{array}{l}\text { It characterized by high yield, earliness and } \\
\text { high boll weight. }\end{array}$ \\
\hline
\end{tabular}

Experimental design:

In the first season (2012), $F_{2}$ of the two populations as well as original parents were grown in non-replicated rows(rows $7.5 \mathrm{~m}$ long, $0.60 \mathrm{~m}$ width and 20 hills/ row). All plants were self pollinated. Selection in each population were made on the basis of number of retained open bolls and productivity of individual plant. Selfed as well as open pollinated bolls per plant were picked up separately, to determine seed cotton yield and lint yield per plant. In addition, yield component traits i.e., boll weight (B.W.), seed cotton yield (S.C.Y.), lint yield (L.Y.), lint percentage (L.\%), seed index (S.I.), lint index (L.I.), Number of bolls/plant (No. B./P.) and Number of seeds/boll (No. S./B.) were determined for $F_{2}$ plants, in addition to the earliness index in $F_{3}$ families which was estimated by the following equation:

first picking

first picking + second picking

The top $10 \%$ of superior plants in $F_{2}$ were selected according to seed cotton yield, lint yield, lint percentage, seed index, lint index, number of bolls per plant and boll weight, to decent the new progenies in the next year.

In 2013 cotton growing season, a part of seeds of the $F_{2}$ selected plants for the two populations were grown to produce $F_{3}$ progenies which evaluated with their original parents and the commercial variety Giza86 under the two planting dates. $F_{3}$ progeny was grown in three replicates. Seeds of $F_{3}$ were sown in hills spaced $0.3 \mathrm{~m}$ and thinned to two plants per hill. Randomized Complete Block Design (RCBD) was used in this experiment.

Observations were scored on 15 single plants, five guarded plants per replication were chosen randomly. The selection procedures were based on progeny performance in the replicated trails. The highest $10 \%$ of superior progenies according to seed cotton yield, lint percentage, lint index and earliness index to select 80 and 78 families of population I and II, respectively of $\mathrm{F}_{3}$ generation.

Statistical analysis:

Estimates of genotypic and phenotypic variances (Al-Jibouri et al., 1958), heritability in broad sense $\left(\mathrm{h}^{2}{ }_{\mathrm{b}} \%\right)$, phenotypic (PCV) and genotypic (GCV) coefficients of variation were calculated (Burton, 1952). LSD method of comparison was used to compare means. 
Ali, A. A. et al.

Variance components were estimated according to the following formula:
$\sigma^{2} \mathbf{p}=\left(\sigma^{2} \mathbf{g}+\sigma^{2} \mathbf{e}\right) / r+\sigma^{2} \mathbf{s} / r i$
$\sigma^{2} \mathbf{g}=(\mathrm{Mf}-\mathrm{Me}) / \mathrm{ri}$
$\sigma^{2} \mathbf{e}=(\mathrm{Me}-\mathrm{Ms}) / \mathrm{ri}$
$\sigma^{2} \mathbf{s}=M s$

Where:

$r$ : Number of replicates.

I: Number of plants per plot.

Table 2: Analysis of variance of plants per plot in $F_{3}$ of two populations

\begin{tabular}{|l|c|c|l|}
\hline \multicolumn{1}{|c|}{ S.O.V. } & D.F. & M.S. & \multicolumn{1}{|c|}{ E.M.S. } \\
\hline Families & $(\mathrm{f}-1)$ & $\mathrm{Mf}$ & $\sigma^{2} \mathrm{~s}+\mathrm{i} \sigma^{2} \mathrm{e}+\mathrm{ri} \sigma^{2} \mathrm{~g}$ \\
\hline Replications & $(\mathrm{r}-1)$ & $\mathrm{Mr}$ & \\
\hline Experimental error & $(\mathrm{r}-1)(\mathrm{f}-1)$ & $\mathrm{Me}$ & $\sigma^{2} \mathrm{~s}+\mathrm{i} \sigma^{2} \mathrm{e}$ \\
\hline Sampling error & $\mathrm{rf}(\mathrm{i}-1)$ & $\mathrm{Ms}$ & $\sigma^{2} \mathrm{~s}$ \\
\hline Total & $\mathrm{rfi}-1$ & & \\
\hline
\end{tabular}

Variance components for the studied traits were estimated according to the following formula:

$$
\begin{array}{cc}
P C V=\frac{\sqrt{\sigma^{2} p}}{\bar{x}} \times 100 & G C V=\frac{\sqrt{\sigma^{2} g}}{\bar{x}} \times 100 \\
h_{b}^{2} \%= & \frac{\sigma^{2} g}{\sigma^{2} p} \times 100
\end{array}
$$

Where:

$\sigma^{2} p$ : Phenotypic variance.

$\sigma^{2} g$ : Genotypic variance.

$h_{b}^{2} \%$ : Heritability in broad sense.

Observed gain:

Observed gain for better original parent and commercial variety (Giza 86) was estimated by the following equation (Mahdy et al., 2007):-

Where :

$$
\frac{\bar{x}_{F-} \bar{x}_{B \text { or } C}}{\bar{x}_{B \text { or } C}} \times 100
$$

$\bar{x}_{F}$ : Mean of the high family.

$\bar{X}_{B \text { or } C}$ : Means of better or commercial variety. 


\section{RESULTS AND DISCUSSION}

Estimate of genotypic and phenotypic coefficients of variation as well as heritability in broad sense $\left(h_{b}^{2} \%\right)$ in the two population (I and II) are shown in Table 3. In $F_{2}$ generation under late planting date, GCV of seed cotton yield per plant as a criteria of selection was 32.52 and $33.34 \%$ in population I and II, respectively. While, GCV of seed cotton yield/ plant was 16.29 and $34.74 \%$ and 17.30 and $13.99 \%$ for the two $F_{3}$ populations under both planting dates, respectively.

GCV and PCV of boll weight, seed cotton yield, lint yield, lint percentage, seed index, lint index, number of bolls/ plant and number of seeds / boll of $F_{2}$ generation were higher than the GCV and PCV of the same traits in $F_{3}$ generation under the two planting date for population I and II, respectively except for $\mathrm{PCV}$ of boll weight in $\mathrm{F}_{2}$ population II which was lower than the PCV in $\mathrm{F}_{3}$ for population II under conventional planting date. Also, PCV and GCV of seed index of $F_{2}$ in population II were lower than the PCV and GCV of $F_{3}$ in the same population under conventional planting date. Although, the large amount of variability in $\mathrm{F}_{2}$ generation heritability in broad sense $\left(h_{b}^{2} \%\right)$ of all studied traits were lower than $\mathrm{F}_{3}$ generation under the two planting dates for populations I and II except lint percentage and seed index in $F_{2}$ and $F_{3}$ generations in population II. These results were in agreement with those obtained by Badeaa (2011), who was found that heritability in broad sense $\left(h_{b}^{2} \%\right)$ in $\mathrm{F}_{3}$ generation was higher than the $h_{b}^{2} \%$ in $\mathrm{F}_{2}$ generation. But, Mahdy et al., (2001) reported that heritability in broad sense $\left(h_{b}^{2} \%\right)$ estimates from $\mathrm{F}_{2}$ generation were generally high for seed cotton yield per plant and correlated traits because of the large portion of non additive effects.. Also, the results cleared that the difference between the GCV and $\mathrm{PCV}$ in $\mathrm{F}_{2}$ generation was due to the large of environmental effects. Larsson et al., (1997) reported that the estimates of genetic parameters such as heritabilities and genetic correlation may vary even within relatively short time periods in natural population because of presence of genotype $\times$ environment interaction. The differences between generations may be due to the various genotypes scored by each selection index, the genetic variability within $F_{2}$ plots that would be greater than within $\mathrm{F}_{3}$ progeny rows, the genotype by environment interactions which may be of large magnitude and the possible considerable dominance gene action present and expressed in an $F_{2}$ population which is the one we consider most likely Meredith and Bridge (1973), El-Mansy (2005) and Abd El-Salam (2005).

Mean performance of the 30 selected families from population I for the nine studied traits were presented in Table 4. For boll weight there was one family (No. 319) showed highly significant values compared with better parent and commercial variety (Giza86). 
Ali, A. A. et al. 
Mean values of seed cotton yield / plant ranged from $24.78 \mathrm{~g}$ for family No. 204 to $56.79 \mathrm{~g}$ for family No. 186. Seven families No. 52, 61, 143, 165, 186, 198 and 253 were higher than the better parent but they did not differ significantly in addition these families did not differ significantly compared with the better parent in the earliness index. Moreover, two families No. 140 and 184 were higher than the better parent for earliness index.

Table 4: Mean performance of the 30 selected families from population I based on seed cotton yield per plant, lint percentage, lint index and earliness index under the conventional planting date in 2013 cotton growing season.

\begin{tabular}{|c|c|c|c|c|c|c|c|c|c|}
\hline \multirow[b]{2}{*}{ Selected families } & \multicolumn{9}{|c|}{ Traits } \\
\hline & $\begin{array}{c}\text { B.W. } \\
\text { (g) }\end{array}$ & $\begin{array}{c}\text { S.C.Y. } \\
\text { (g) }\end{array}$ & $\begin{array}{l}\text { L.Y. } \\
\text { (g) }\end{array}$ & L.P. & S.I. & E.I. & L.I. & $\begin{array}{l}\text { No. } \\
\text { B./P. }\end{array}$ & $\begin{array}{l}\text { No. } \\
\text { S./B. }\end{array}$ \\
\hline 46 & 2.32 & 32.28 & 11.8 & 36.42 & 7.68 & 81.44 & 4.43 & 14.14 & 19.3 \\
\hline 52 & 2.71 & 53.31 & 20.62 & 38.81 & 9.00 & 60.91 & 5.72 & 19.66 & 18.5 \\
\hline 57 & 2.79 & 37.67 & 14.85 & 39.32 & 9.73 & 60.41 & 6.34 & 13.44 & 17.4 \\
\hline 60 & 2.58 & 46.22 & 16.14 & 35.00 & 8.25 & 61.93 & 4.45 & 18.32 & 20.5 \\
\hline 61 & 2.70 & 52.45 & 19.40 & 36.96 & 9.40 & 61.16 & 5.51 & 19.69 & 18.1 \\
\hline 81 & 2.92 & 32.45 & 8.57 & 38.84 & 9.69 & 64.25 & 6.17 & 11.02 & 18.4 \\
\hline 130 & 2.52 & 37.70 & 13.78 & 36.55 & 8.39 & 76.65 & 4.86 & 14.64 & 19.3 \\
\hline 140 & 2.84 & 44.40 & 17.40 & 38.77 & 9.03 & 86.22 & 5.74 & 15.67 & 19.4 \\
\hline 143 & 2.69 & 53.84 & 20.90 & 38.91 & 8.43 & 78.63 & 5.36 & 20.09 & 19.6 \\
\hline 157 & 2.44 & 39.88 & 15.46 & 38.18 & 8.35 & 79.31 & 5.22 & 16.11 & 18.3 \\
\hline 161 & 2.58 & 36.36 & 13.64 & 37.45 & 8.77 & 76.19 & 5.26 & 14.01 & 18.1 \\
\hline 165 & 3.02 & 48.79 & 17.82 & 36.52 & 9.13 & 73.10 & 5.26 & 16.20 & 21.1 \\
\hline 168 & 2.51 & 40.88 & 15.35 & 37.66 & 8.04 & 79.58 & 4.86 & 16.21 & 19.6 \\
\hline 184 & 2.54 & 34.83 & 13.11 & 37.60 & 8.32 & 87.08 & 5.00 & 13.83 & 19.2 \\
\hline 186 & 3.17 & 56.79 & 22.27 & 39.10 & 9.67 & 68.82 & 6.21 & 18.37 & 20.0 \\
\hline 187 & 2.36 & 43.65 & 16.87 & 38.79 & 8.52 & 57.50 & 5.46 & 18.79 & 16.6 \\
\hline 198 & 2.94 & 50.62 & 19.00 & 37.56 & 9.55 & 66.49 & 5.76 & 17.42 & 19.3 \\
\hline 204 & 2.03 & 24.78 & 9.14 & 36.43 & 7.24 & 78.46 & 4.20 & 12.49 & 17.9 \\
\hline 230 & 2.97 & 32.89 & 13.29 & 40.64 & 9.12 & 58.94 & 6.25 & 11.06 & 19.5 \\
\hline 237 & 3.01 & 46.59 & 17.20 & 36.99 & 9.37 & 71.74 & 5.51 & 15.56 & 20.3 \\
\hline 240 & 3.08 & 44.17 & 16.71 & 37.53 & 10.29 & 55.52 & 6.24 & 14.30 & 18.6 \\
\hline 241 & 3.33 & 46.13 & 17.81 & 38.55 & 10.60 & 68.77 & 6.66 & 13.99 & 19.3 \\
\hline 243 & 3.05 & 30.37 & 11.75 & 38.81 & 9.05 & 74.67 & 5.74 & 9.89 & 20.9 \\
\hline 244 & 2.88 & 38.49 & 14.91 & 38.78 & 9.57 & 62.07 & 6.11 & 13.34 & 18.4 \\
\hline 246 & 3.09 & 41.81 & 15.74 & 37.72 & 9.83 & 63.86 & 6.05 & 13.33 & 19.5 \\
\hline 249 & 3.32 & 37.93 & 14.45 & 38.21 & 9.77 & 68.82 & 6.06 & 11.46 & 21.1 \\
\hline 253 & 3.00 & 48.29 & 17.56 & 36.26 & 9.52 & 51.92 & 5.44 & 16.17 & 20.2 \\
\hline 319 & 4.83 & 35.60 & 14.09 & 40.05 & 8.49 & 59.11 & 5.65 & 12.33 & 23.8 \\
\hline 336 & 2.82 & 45.58 & 17.21 & 37.84 & 8.8 & 59.86 & 5.35 & 16.47 & 20.1 \\
\hline 367 & 2.91 & 35.04 & 13.44 & 38.33 & 9.47 & 59.24 & 5.94 & 11.98 & 18.9 \\
\hline Overall mean & 2.71 & 37.97 & 14.05 & 37.03 & 8.91 & 66.16 & 5.27 & 14.25 & 19.2 \\
\hline Better parent & 3.15 & 47.30 & 19.7 & 41.7 & 9.74 & 83.08 & 6.95 & 15.00 & 18.9 \\
\hline Commercial variety & 3.04 & 42.3 & 17.3 & 40.9 & 9.23 & 72.01 & 6.30 & 13.9 & 19.6 \\
\hline LSD 0.05 & 0.36 & 10.04 & 3.86 & 1.6 & 0.97 & 7.99 & 0.71 & 3.24 & 2.5 \\
\hline LSD 0.01 & 0.47 & 13.23 & 5.1 & 2.13 & 1.21 & 10.53 & 0.94 & 4.28 & 3.3 \\
\hline
\end{tabular}

Overall mean represents means of 80 selected families. 
Concerning seed cotton yield, four families No. 52, 61, 143 and 186, gave the higher values and significantly differed from the commercial variety (Giza86).

Thus selection for seed cotton yield caused adverse effects on earliness and resulted in late mature families. These results were in agreement with those reported by Mahdy et al., (2001). Generally the previous results due to the better parent reveled that the hybrid (10229×Giza86) had the highest promising variety among Egyptian cotton varieties for seed cotton yield and earliness at the present time. For lint yield three families No. 52, 143 and 186 were higher than the better parent but, they did not differ significantly. Also the seven families No. 57, 81, 186, 240, 241246 and 249 had the higher values than the better parent for seed index. For lint index, all families were lower than the better parent and the commercial variety (Giza86). Values of number of bolls per plant of the families No. 52, 61 and 143 showed the high significant estimates compared with the better parent and values of the families No. 60, 186 and 187 were differed significantly. Also there were six families No. 52, 60, 61, 143, 186 and 187 showed highly significant values compared with the commercial variety and only family No. 198 was differed significantly. With respect to number of seeds per boll there was one family (No. 319) differed highly significant compared with the better parent and the commercial variety (Giza86).

\section{Mean performance of the thirty selected families from population I under late planting date:}

Mean values were presented in Table 5 , showed that for boll weight there was only one family No. 165 differed significant compared to the better parent. While, all families were differed significantly with the commercial variety (Giza 86) except families No. 52, 185, 198, 206 and 213.

Seed cotton yield / plant ranged from $15.29 \mathrm{~g}$ for family No. 213 to $68.55 \mathrm{~g}$ for family No. 58. Families No. 2, 55, 58, 165, 184, 198, 207, 237, 246 and 249 were higher than the better parent for seed cotton yield and lint yield but they did not significantly differed among them, except family No. 58 was highly significant for the two traits. The four families No. 58, 165, 184, and 246 were highly significant compared to commercial variety for the both traits. While, families No. 198 and 207 was differed significant for seed cotton yield and lint yield, respectively. For lint percentage families No. 108, 204, 206 and 241 were highly significant compared to the better parent, the families No. 108, 204, 206, 207, 241 and 289 as well as the four families No. 14, 198, 204 and 243 showed highly significant and significant values compared to the commercial variety. For seed index values of the four families No. 2, 68, 102 and 165 were highly significant and the values of families No. 140 and 161 were significant compared to the better parent. Moreover, values of all families were significant or highly significant compared to the commercial variety Giza86 except families No. 55, 185, 204, 237 and 289 which did not have significantly differed. Regarding early index all selected families were not higher than the better parent. While, all families except families No. 14, 25, 68, 108, 140, 207, 241, 243 and 289 were highly significant compared with the commercial variety. For lint index, the nine families No. 2, 68, 102, 108, 109, 140, 161, 165 and 241were 
highly significant compared to the better parent, in addition families No. 14, $25,206,207,246$ and 381 were significant compared to the same parent. Compared to the commercial variety all families were highly significant and significant except families No. 52, 55, 57, 185, 198 and 367. For number of bolls per plant four families No. 58, 184, 198 and 246 were highly significant compared to the better parent and five families No. 55, 165, 207, 237 and 249 were differed significantly. On the other hand, the families No. 58, 184, 198 were highly significant and only one family No. 246 was significant compared to the commercial variety (Giza86). For number of seeds per boll all families were not significant compared to the better parent and the commercial variety, except family No. 55 which was highly significant for the commercial variety.

Table 5: Mean performance of the $\mathbf{3 0}$ selected families from population I based on seed cotton yield per plant, lint percentage, lint index and earliness index under the late planting date in 2013 cotton growing season.

\begin{tabular}{|c|c|c|c|c|c|c|c|c|c|}
\hline \multirow[b]{2}{*}{$\begin{array}{l}\text { Selected } \\
\text { families }\end{array}$} & \multicolumn{9}{|c|}{ Traits } \\
\hline & $\begin{array}{l}\text { B.W. } \\
(\mathrm{g})\end{array}$ & $\begin{array}{l}\text { S.C.Y. } \\
\text { (g) }\end{array}$ & $\begin{array}{l}\text { L.Y. } \\
(\mathrm{g})\end{array}$ & L.P. & S.I. & E.I. & L.I. & $\begin{array}{l}\text { No. } \\
\text { B./P. }\end{array}$ & $\begin{array}{l}\text { No. } \\
\text { S./B. }\end{array}$ \\
\hline 2 & 4.1 & 41.72 & 15.80 & 37.70 & 12.26 & 64.68 & 7.43 & 12.92 & 21.03 \\
\hline 11 & 3.9 & 40.50 & 14.6 & 36.50 & 11.10 & 64.20 & 6.40 & 13.50 & 22.50 \\
\hline 14 & 4.1 & 32.64. & 12.98 & 39.79 & 10.68 & 58.95 & 7.06 & 11.33 & 23.41 \\
\hline 25 & 3.6 & 22.89 & 9.00 & 39.54 & 10.66 & 53.86 & 6.96 & 9.64 & 20.19 \\
\hline 52 & 3.1 & 36.16 & 13.16 & 36.13 & 10.12 & 70.22 & 5.76 & 14.48 & 19.75 \\
\hline 55 & 3.7 & 44.25 & 16.93 & 38.49 & 9.64 & 67.71 & 6.05 & 15.25 & 23.81 \\
\hline 57 & 3.4 & 40.88 & 14.95 & 36.60 & 10.30 & 67.85 & 5.93 & 14.77 & 20.90 \\
\hline 58 & 3.7 & 68.55 & 25.09 & 36.63 & 10.84 & 77.19 & 6.27 & 21.09 & 21.81 \\
\hline 68 & 4.1 & 18.50 & 7.20 & 38.90 & 12.8 & 47.70 & 8.20 & 7.50 & 19.70 \\
\hline 102 & 3.6 & 35.77 & 13.12 & 36.91 & 12.42 & 66.40 & 7.26 & 12.96 & 18.48 \\
\hline 108 & 3.5 & 16.47 & 6.84 & 41.25 & 10.94 & 49.01 & 7.66 & 7.64 & 18.78 \\
\hline 109 & 3.7 & 33.64 & 13.27 & 39.38 & 11.24 & 63.06 & 7.32 & 12.11 & 19.96 \\
\hline 140 & 4.2 & 29.99 & 11.55 & 38.64 & 11.92 & 58.22 & 7.52 & 10.32 & 21.49 \\
\hline 161 & 3.8 & 38.45 & 14.77 & 38.41 & 11.70 & 64.85 & 7.32 & 13.25 & 20.32 \\
\hline 165 & 4.3 & 53.51 & 20.55 & 38.36 & 12.54 & 69.57 & 7.84 & 15.71 & 20.98 \\
\hline 184 & 3.7 & 54.42 & 21.05 & 38.38 & 10.80 & 73.32 & 6.74 & 18.01 & 21.2 \\
\hline 185 & 3.2 & 36.35 & 13.41 & 37.01 & 9.48 & 69.18 & 5.57 & 14.42 & 21.06 \\
\hline 198 & 3.1 & 53.03 & 19.20 & 36.40 & 9.90 & 76.70 & 5.60 & 20.40 & 19.80 \\
\hline 204 & 3.3 & 28.62 & 11.88 & 41.06 & 9.70 & 62.05 & 6.75 & 11.74 & 20.09 \\
\hline 206 & 3 & 24.61 & 9.88 & 41.30 & 9.94 & 63.12 & 7.04 & 11.04 & 17.85 \\
\hline 207 & 3.7 & 46.51 & 18.82 & 40.75 & 10.10 & 63.00 & 6.97 & 15.94 & 21.67 \\
\hline 213 & 2.9 & 15.29 & 6.10 & 39.83 & 9.84 & 38.91 & 6.53 & 5.29 & 17.61 \\
\hline 237 & 3.5 & 42.04 & 16.56 & 39.30 & 9.66 & 70.71 & 6.27 & 15.51 & 21.63 \\
\hline 241 & 3.6 & 33.95 & 14.05 & 42.05 & 11.36 & 60.02 & 8.27 & 12.77 & 18.30 \\
\hline 243 & 3.6 & 19.92 & 7.88 & 39.76 & 9.86 & 51.44 & 6.57 & 8.46 & 21.87 \\
\hline 246 & 3.8 & 54.02 & 20.85 & 38.99 & 10.90 & 71.37 & 6.98 & 16.99 & 21.36 \\
\hline 249 & 3.3 & 42.13 & 16.47 & 38.87 & 9.94 & 71.91 & 6.32 & 15.70 & 20.20 \\
\hline 289 & 3.5 & 26.71 & 10.77 & 40.35 & 9.36 & 61.34 & 6.35 & 10.68 & 22.18 \\
\hline 367 & 3.6 & 40.50 & 15.30 & 37.60 & 10.00 & 69.40 & 6.00 & 14.30 & 22.70 \\
\hline 381 & 3.9 & 39.07 & 14.94 & 38.15 & 11.58 & 67.24 & 7.13 & 13.01 & 20.84 \\
\hline Overall mean & 3.5 & 29.89 & 11.44 & 38.30 & 10.43 & 59.91 & 6.50 & 11.47 & 20.85 \\
\hline Better parent & 3.7 & 41.30 & 15.60 & 38.50 & 10.60 & 77.20 & 6.00 & 11.00 & 22.20 \\
\hline $\begin{array}{c}\text { Commercial } \\
\text { Variety }\end{array}$ & 2.7 & 32.30 & 12.10 & 37.60 & 8.60 & 48.40 & 5.20 & 12.00 & 19.90 \\
\hline LSD 0.05 & 0.56 & 15.43 & 6.02 & 1.77 & 1.14 & 10.05 & 0.88 & 4.03 & 2.91 \\
\hline LSD 0.01 & 0.73 & 20.29 & 7.92 & 2.32 & 1.50 & 13.21 & 1.16 & 5.30 & 3.83 \\
\hline
\end{tabular}

Overall mean represents means of 80 selected families. 
Mean performance of nine traits for the 30 selected families from population II (GIZA75×Sea Island) $\times$ Australian13 were presented in Table 6 . all Mean values of seed cotton yield per plant did not differ significantly than the better parent and they ranged from 33.40 to $59.50 \mathrm{~g}$. For boll weight trait one family No. 306 was high and significant compared to the better parent and the commercial variety. Regarding seed cotton yield, all families were not significant compared to the better parent and the families No. 100, 141, 154, $173,188,211,215,217,235,247,321,372$ and 373 were highly significant compared to the earlier parent, in addition the two families No.

Table 6: Mean performance of the $\mathbf{3 0}$ selected families from population II based on seed cotton yield per plant, lint percentage, lint index and earliness index under the conventional planting date in 2013 cotton growing season.

\begin{tabular}{|c|c|c|c|c|c|c|c|c|c|}
\hline \multirow[b]{2}{*}{ Selected families } & \multicolumn{9}{|c|}{ Traits } \\
\hline & $\begin{array}{c}\text { B.W. } \\
\text { (g) }\end{array}$ & $\begin{array}{c}\text { S.C.Y. } \\
\text { (g) }\end{array}$ & $\begin{array}{l}\text { L.Y. } \\
\text { (g) }\end{array}$ & L.P. & S.I. & E.I. & L.I. & $\begin{array}{l}\text { No. } \\
\text { B./P. }\end{array}$ & $\begin{array}{l}\text { No. } \\
\text { S./B. }\end{array}$ \\
\hline 93 & 3.2 & 42.4 & 16.6 & 38.9 & 10.2 & 77.5 & 6.5 & 13.2 & 19.4 \\
\hline 100 & 2.5 & 55.1 & 21.3 & 38.2 & 7.4 & 84.8 & 4.6 & 20.9 & 21.1 \\
\hline 125 & 3.3 & 53.7 & 21.6 & 40.0 & 10.3 & 82.0 & 6.9 & 16.2 & 19.6 \\
\hline 126 & 3.1 & 40.4 & 16.0 & 39.6 & 9.8 & 80.4 & 6.4 & 12.9 & 19.2 \\
\hline 128 & 3.1 & 54.3 & 21.5 & 39.4 & 9.3 & 72.3 & 6.1 & 17.8 & 20.2 \\
\hline 141 & 2.6 & 42.2 & 16.9 & 40.2 & 8.8 & 87.2 & 5.9 & 16.2 & 17.8 \\
\hline 154 & 3.4 & 49.7 & 19.8 & 39.9 & 10.5 & 84.8 & 7.0 & 14.4 & 19.6 \\
\hline 160 & 3.3 & 59.1 & 24.0 & 40.5 & 10.7 & 63.9 & 7.3 & 17.9 & 18.7 \\
\hline 172 & 3.3 & 48.3 & 18.7 & 38.8 & 10.3 & 80.1 & 6.6 & 14.7 & 19.7 \\
\hline 173 & 3.0 & 49.6 & 19.6 & 39.3 & 9.2 & 87.6 & 5.9 & 16.4 & 19.9 \\
\hline 179 & 3.7 & 38.0 & 14.8 & 39.3 & 10.2 & 74.3 & 6.6 & 10.2 & 21.9 \\
\hline 188 & 3.0 & 48.3 & 19.3 & 40.1 & 9.1 & 86.2 & 6.1 & 16.3 & 19.9 \\
\hline 193 & 3.1 & 52.6 & 21.5 & 41.0 & 9.5 & 73.1 & 6.6 & 17.0 & 19.1 \\
\hline 203 & 3.5 & 55.9 & 22.8 & 40.7 & 9.2 & 75.7 & 6.3 & 16.0 & 22.7 \\
\hline 211 & 2.9 & 45.6 & 18.2 & 40.0 & 7.8 & 86.8 & 5.2 & 15.8 & 22.4 \\
\hline 215 & 3.0 & 51.1 & 21.2 & 41.3 & 8.8 & 87.8 & 6.2 & 17.3 & 20.2 \\
\hline 217 & 3.1 & 55.6 & 22.1 & 39.7 & 9.1 & 83.2 & 6.0 & 17.8 & 20.9 \\
\hline 235 & 2.8 & 45.3 & 18.1 & 40.0 & 8.5 & 86.8 & 5.7 & 16.2 & 20.1 \\
\hline 247 & 3.0 & 51.7 & 20.2 & 39.1 & 9.0 & 87.1 & 5.8 & 17.5 & 20.0 \\
\hline 254 & 3.0 & 46.4 & 19.5 & 41.9 & 8.5 & 81.2 & 6.2 & 15.7 & 20.4 \\
\hline 266 & 2.6 & 41.9 & 17.3 & 41.0 & 7.8 & 77.3 & 5.4 & 15.9 & 19.9 \\
\hline 282 & 2.7 & 37.9 & 15.7 & 41.3 & 8.1 & 68.6 & 5.7 & 14.2 & 19.6 \\
\hline 289 & 2.4 & 33.4 & 13.8 & 41.1 & 7.3 & 75.5 & 5.1 & 13.7 & 19.4 \\
\hline 306 & 3.0 & 59.5 & 24.4 & 41.0 & 9.4 & 71.2 & 6.5 & 20.0 & 18.9 \\
\hline 307 & 3.2 & 37.5 & 15.7 & 41.7 & 9.4 & 74.6 & 6.7 & 11.7 & 19.7 \\
\hline 310 & 4.8 & 35.5 & 14.6 & 41.0 & 8.8 & 66.4 & 6.1 & 12.5 & 21.3 \\
\hline 321 & 3.0 & 53.6 & 22.1 & 41.4 & 8.9 & 83.2 & 6.3 & 17.4 & 20.0 \\
\hline 358 & 3.0 & 37.8 & 15.6 & 41.2 & 8.8 & 73.8 & 6.2 & 13.0 & 19.8 \\
\hline 372 & 2.7 & 41.5 & 16.6 & 40.1 & 7.7 & 87.5 & 5.2 & 15.3 & 21.3 \\
\hline 373 & 2.8 & 44.9 & 17.5 & 39.1 & 8.7 & 87.8 & 5.6 & 15.9 & 19.3 \\
\hline Overall mean & 2.9 & 41.8 & 16.6 & 39.5 & 8.7 & 76.9 & 5.7 & 14.4 & 20.4 \\
\hline Better parent & 3.0 & 50.6 & 19.2 & 39.9 & 9.2 & 74.4 & 5.7 & 16.7 & 20.5 \\
\hline Commercial variety & 3.0 & 42.3 & 17.3 & 40.9 & 9.2 & 72.1 & 6.4 & 13.9 & 19.6 \\
\hline LSD 0.05 & 0.82 & 13.0 & 4.8 & 1.4 & 0.96 & 6.26 & 0.69 & 3.3 & 5.1 \\
\hline LSD 0.01 & 1.07 & 15.8 & 6.3 & 1.8 & 1.26 & 8.23 & 0.91 & 4.323 & 6.7 \\
\hline
\end{tabular}

Overall mean represents means of 78 selected families. 
125 and 254 were significantly differed. While, mean values of seed cotton yield per plant showed that the two families No. 160 and 306 and families No. 203 and 217 were highly significantly and significant compared to the better parent, respectively. But these families were late in maturity except the family No. 215. These results were in agreement with Mahdy et al., (2007) who reported that selection for seed cotton yield caused adverse effects on earliness and resulted in late mature families. Therefore, it will be feasible to look for earliness index when selection was practiced for yield. Mean values of lint yield showed that the two families No. 160 and 306 were significantly differed in seed cotton yield and also significantly differed compared to the better parent and the commercial variety, respectively. In addition, the families No. 203, 217 and 321 were significant. For lint percentage trait, there were not any family significantly differed from the better parent or the commercial variety. For seed index, the families No. 93, 125, 172 and 179 were significantly differed compared to the better parent and the commercial variety (Giza86). While, the two families No. 154 and 160 were highly

Significant compared with the better parent and commercial variety. For number of bolls/ plant families No. 100 and 306 were significant compared to better parent, while families No. 100 and 306 were highly significant for commercial variety and families No. 128, 160, 215, 217, 247 and 321 were differed significant compared to commercial variety. For lint index, the families No. 125, 154, 160,172,179,193 and 307 were differed highly significant and families No. 93, 126 and 306 differed significant compared to better parent, respectively. While, only one family No. 160 was differed highly significantly compared to commercial variety. For number of seeds per boll, all families were not differed significantly compared with better parent and commercial variety, respectively.

Mean performance of the 30 selected families of population II under late planting date were presented in Table 7. Mean values of seed cotton yield ranged from $33.20 \mathrm{~g}$ for family No. 343 to $62.25 \mathrm{~g}$ for family No. 304 . For boll weight, mean values of all families differed significantly or highly significant from the commercial variety (Giza86), except four families No. 5, 56, 117 and 141. All families did not significantly differed from the better parent. For seed cotton yield, the families No.77, 100, 173, 186, 282, 304 and 313 mean values were differed significantly compared to the better parent. While, the mean values of 15 families differed significantly or highly significant from the commercial variety. The same trend was observed in the earliness index since mean values of all families were significantly differed or highly significantly compared to the commercial variety except the families No. 172 and 343 compared to better parent but the two families No. 215 and 372 were differed significantly compared to the better parent. For lint yield seven families were differed significantly compared to the better parent and only one family was highly significant. While, 26 families were significant or highly significantly compared to the commercial variety. For the trait of lint percentage, the five families No. 5, 93, 204, 259 and 343 showed high significant estimates compared to the better parent. While, families No. 41, $111,141,172,179,211,217,282$ and 318 were differed significantly on the other hand, the families No. 5, 41, 93, 141, 204, 259, and 343 were highly 
significant and families No. 111, 172, 179, 211, 217, 282, 318 and 373 were differed significantly compared to the commercial variety. For seed index all selected families did not differ significantly compared to the better parent while, 18 families were highly significant compared to the commercial variety and the families No. 100, 179, 282, 318 and 374 were differed significantly. For number of bolls / plant, five families No. 100, 179, 282, 318 and 304 were highly significant compared to the better parent and the commercial variety (Giza86). The seven families No.

Table 7: Mean performances of the 30 selected families from population II based on seed cotton yield per plant, lint percentage, lint index and earliness index under the late planting date in 2013 cotton growing season.

\begin{tabular}{|c|c|c|c|c|c|c|c|c|c|}
\hline \multirow[b]{2}{*}{$\begin{array}{l}\text { Selected } \\
\text { families }\end{array}$} & \multicolumn{9}{|c|}{ Traits } \\
\hline & $\begin{array}{l}\text { B.W. } \\
\text { (g) }\end{array}$ & $\begin{array}{l}\text { S.C.Y. } \\
\text { (g) }\end{array}$ & $\begin{array}{l}\text { L.Y. } \\
\text { (g) }\end{array}$ & L.P. & S.I. & E.I. & L.I. & $\begin{array}{l}\text { No. } \\
\text { B./P. }\end{array}$ & $\begin{array}{l}\text { No. } \\
\text { S./B. }\end{array}$ \\
\hline 5 & 3.07 & 33.88 & 13.45 & 40.00 & 9.40 & 60.19 & 6.26 & 11.14 & 19.71 \\
\hline 41 & 3.41 & 43.40 & 17.13 & 39.61 & 10.58 & 67.29 & 6.94 & 12.81 & 19.58 \\
\hline 56 & 3.14 & 51.08 & 19.72 & 38.71 & 9.60 & 72.25 & 6.07 & 15.92 & 19.96 \\
\hline 77 & 3.47 & 57.31 & 22.05 & 38.61 & 10.22 & 70.09 & 6.42 & 16.41 & 20.98 \\
\hline 93 & 3.70 & 51.89 & 20.84 & 40.54 & 10.80 & 67.65 & 7.32 & 13.92 & 20.68 \\
\hline 100 & 3.38 & 60.23 & 22.68 & 37.71 & 9.86 & 72.79 & 5.97 & 18.13 & 21.43 \\
\hline 111 & 3.47 & 43.12 & 17.08 & 39.48 & 10.45 & 63.92 & 6.86 & 12.63 & 20.20 \\
\hline 117 & 3.13 & 52.29 & 20.19 & 38.72 & 9.63 & 72.54 & 6.08 & 17.02 & 19.84 \\
\hline 141 & 3.13 & 37.93 & 15.01 & 39.61 & 9.72 & 63.83 & 6.38 & 12.39 & 19.53 \\
\hline 172 & 3.22 & 38.04 & 15.05 & 39.41 & 10.00 & 59.10 & 6.52 & 11.92 & 19.84 \\
\hline 179 & 3.40 & 57.32 & 22.74 & 39.45 & 9.82 & 73.34 & 6.42 & 17.15 & 20.99 \\
\hline 183 & 3.34 & 43.39 & 17.00 & 39.01 & 10.32 & 66.21 & 6.62 & 12.97 & 19.80 \\
\hline 186 & 3.65 & 58.89 & 22.71 & 38.54 & 10.86 & 73.35 & 6.83 & 16.41 & 20.81 \\
\hline 204 & 3.61 & 34.07 & 13.73 & 39.91 & 10.46 & 54.98 & 6.95 & 9.40 & 20.82 \\
\hline 211 & 3.47 & 55.75 & 22.01 & 39.41 & 10.12 & 70.42 & 6.63 & 16.20 & 20.88 \\
\hline 215 & 3.40 & 56.49 & 21.91 & 38.91 & 10.04 & 74.43 & 6.41 & 17.15 & 20.63 \\
\hline 217 & 3.4 & 45.32 & 17.76 & 39.37 & 10.34 & 66.5 & 6.7 & 13.3 & 20.1 \\
\hline 259 & 3.38 & 40.45 & 16.17 & 40.02 & 10.44 & 63.34 & 6.97 & 11.81 & 19.43 \\
\hline 282 & 3.17 & 59.22 & 23.37 & 39.47 & 9.94 & 71.31 & 6.49 & 18.94 & 19.39 \\
\hline 304 & 3.45 & 62.25 & 24.18 & 38.84 & 10.76 & 72.88 & 6.84 & 18.12 & 19.76 \\
\hline 306 & 3.44 & 55.03 & 20.22 & 37.97 & 9.70 & 71.04 & 5.95 & 15.97 & 21.98 \\
\hline 313 & 3.61 & 61.61 & 23.62 & 38.24 & 10.62 & 73.58 & 6.58 & 17.14 & 21.07 \\
\hline 315 & 3.38 & 51.43 & 20.01 & 35.8 & 10.02 & 71.37 & 6.4 & 15.10 & 20.8 \\
\hline 318 & 3.3 & 44.2 & 17.3 & 39.3 & 9.80 & 69.5 & 6.4 & 13.70 & 20.2 \\
\hline 321 & 3.28 & 53.14 & 19.87 & 37.19 & 9.26 & 72.58 & 5.51 & 16.23 & 22.23 \\
\hline 343 & 3.2 & 33.2 & 13.2 & 39.9 & 9.30 & 57.7 & 6.2 & 10.30 & 20.8 \\
\hline 358 & 3.26 & 46.81 & 18.28 & 39.09 & 10.62 & 71.08 & 6.81 & 14.46 & 18.69 \\
\hline 372 & 3.41 & 55.74 & 21.32 & 38.24 & 10.56 & 74.33 & 6.55 & 16.44 & 20.07 \\
\hline 373 & 3.55 & 56.52 & 21.91 & 39.11 & 10.34 & 69.85 & 6.64 & 16.01 & 20.97 \\
\hline 374 & 3.2 & 50.95 & 19.1 & 37.4 & 9.80 & 71.9 & 5.9 & 15.70 & 20.3 \\
\hline Overall mean & 3.28 & 44.42 & 17.02 & 38.29 & 9.94 & 65.77 & 6.18 & 13.57 & 20.47 \\
\hline Better parent & 3.5 & 41.2 & 15.6 & 37.8 & 9.80 & 63.1 & 6.00 & 11.9 & 22.7 \\
\hline $\begin{array}{c}\text { Commercial } \\
\text { variety }\end{array}$ & 2.7 & 32.5 & 12.1 & 37.6 & 8.60 & 48.4 & 5.2 & 12.0 & 19.9 \\
\hline LSD 0.05 & 0.47 & 15.98 & 6.2 & 1.5 & 1.2 & 10.9 & 0.797 & 4.5 & 2.7 \\
\hline LSD 0.01 & 0.63 & 21.99 & 8.2 & 1.9 & 1.4 & 14.4 & 1.1 & 5.9 & 3.6 \\
\hline
\end{tabular}

Overall mean represents means of 78 selected families. 
$77,117,179,186,215,313$ and 372 were significantly differed than the better parent and the families No. 117, 179, 215 and 313 were significantly differed for the commercial variety. For number of seeds per boll, all families did not differ significantly than the better parent or the commercial variety. The previous results indicated that, the different genetic advance between the two populations under the two planting dates may not be the most factor which affects estimates of genetic variance such factor includes, type of genetic material and existence of linkage, high frequencies of coupling phase (AB/ab) causes on up ward bias in variances (Hallauer and Miranda, 1981).

Also, the results indicated that mean performance for most families differed under the two planting dates these results could be due to gene expression for these families as a result to change of environment to stress environment. Therefore, selection for more adaptable lines to stress of late planting date; have high yield and yield components should be under the same environment conditions, because of the genetic variance (Falconer, 1981). The differences between generations may be due to the variances genotypes scored by each selection index, the genetic variability within $F_{2}$ plots that would be greater than within $\mathrm{F}_{3}$ progeny rows, the genotype by environment interactions which may be of large magnitude and the possible considerable dominance gene action present and expressed in an $F_{2}$ population which is the one we consider most likely; Meredith and Bridge (1973), El-Mansy (2005) and Abd El-Salam (2005).

The observed direct gain of the best five families which were selected based on seed cotton yield in population I [(10229×Giza86) $\times$ (PimaS6 $\times$ Giza89)]are presented in Table 8 . The observed gain in seed cotton yield / plant as percentage from better parent and commercial variety under conventional sowing date ranged from 7.00 to $20.10 \%$ and ranged from 28.70 to $66.50 \%$ in late sowing date from the better parent. Moreover, it ranged from 19.60 to $34.30 \%$ and from 63.20 to $111.10 \%$ under the conventional and the late sowing dates for the commercial variety (Giza86), respectively. The best five families were not significant compared to better parent for seed cotton yield and early index under conventional sowing date. While, the mean values of the four best families No. 52, 61, 143 and 186 were significant compared to the better parent for number of bolls per plant. The four, three, and the five best families differed significantly compared to commercial variety (Giza 86) for the three traits, seed cotton yield, lint yield and number of bolls per plant under the conventional sowing date. Under the late sowing date for population I , only one family from the best five families No. 165 was differed significant compared to the better parent for boll weight, family No. 58 was highly significantly for seed cotton yield and lint yield, also family No. 165 was significant for seed index. The best five families showed significantly differences compared to better parent for number of bolls/plant. With respect of seed cotton yield, lint yield, seed index, earliness index and number of bolls/plant the best five families exhibited significant mean values compared to the commercial variety (Giza86). Four and three of the best families for boll weight and lint percentage showed significant mean values too. 
Table 8: Observed gain and correlated response after one cycle of pedigree selection for seed cotton yield per plant measured in percentage of the better parent and commercial variety respectively in population I under conventional and late planting date.

\begin{tabular}{|c|c|c|c|c|c|c|c|c|c|c|}
\hline \multirow{2}{*}{\multicolumn{2}{|c|}{ Family number }} & \multicolumn{9}{|c|}{ Traits } \\
\hline & & $\begin{array}{c}\text { B.W. } \\
(g)\end{array}$ & $\begin{array}{l}\text { S.C.Y. } \\
\text { (g) }\end{array}$ & $\begin{array}{l}\text { L.Y. } \\
\text { (g) }\end{array}$ & L.P. & S.I. & E.I. & L.I. & $\begin{array}{l}\text { No. } \\
\text { B./P. }\end{array}$ & $\begin{array}{l}\text { No. } \\
\text { S./B. }\end{array}$ \\
\hline \multicolumn{11}{|c|}{ Conventional planting date } \\
\hline \multirow{5}{*}{ 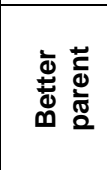 } & 52 & -14 & 12.7 & 3.9 & -6.9 & -7.6 & -27.3 & -18.1 & $31.1^{* *}$ & -2.1 \\
\hline & 61 & -14.3 & 10.9 & -1.5 & -11.4 & -3.4 & -27.0 & -21.1 & $31.3^{\star *}$ & -4.2 \\
\hline & 143 & -14.6 & 13.8 & 6.1 & -6.7 & -13.4 & -6.2 & -23.2 & $33.9^{\star \star}$ & 3.7 \\
\hline & 186 & 0.63 & 20.1 & 13.0 & -6.2 & -0.72 & -17.9 & -11.0 & $22.5^{\star}$ & 5.8 \\
\hline & 198 & -6.7 & 7.00 & -3.6 & -9.9 & -1.9 & -20.7 & -17.5 & 16.1 & 2.1 \\
\hline \multirow{5}{*}{ 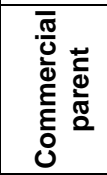 } & 52 & -10.9 & $26.0^{*}$ & 19.2 & -5.1 & -2.5 & -15.5 & -10.3 & $41.4^{\star \star}$ & -5.6 \\
\hline & 61 & -10 & $24.1^{*}$ & 12.1 & -9.5 & 2.2 & -15.2 & -14.1 & $41.7^{\star \star}$ & -7.7 \\
\hline & 143 & -10.3 & $27.2^{*}$ & 20.8 & -4.9 & -8.7 & -.0 & -15.6 & $44.5^{\star \star}$ & 0.00 \\
\hline & 186 & 4.3 & $34.3^{\star \star}$ & $28.9^{* \star}$ & -4.4 & 5.4 & -4.6 & -3.1 & $32.2^{\star \star}$ & 2.0 \\
\hline & 198 & -3.3 & 19.6 & 9.8 & -8.1 & 4.3 & -7.8 & -9.4 & $25.3^{*}$ & -1.5 \\
\hline \multicolumn{11}{|c|}{ Late planting date } \\
\hline \multirow{5}{*}{ 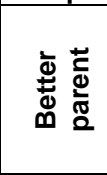 } & 58 & 0.00 & $66.5^{\star *}$ & $60.8^{* *}$ & -4.9 & 2.3 & -0.01 & 4.30 & $77.2^{\star *}$ & -3.9 \\
\hline & 165 & $16.2^{\star *}$ & 29.9 & 31.7 & -3.6 & $18.3^{\star \star}$ & -0.09 & 30.0 & $32.1^{*}$ & -7.5 \\
\hline & 184 & 0.00 & 32.03 & 34.9 & -3.1 & 1.9 & -.5 .02 & 12.3 & $51.3^{\star \star}$ & -6.6 \\
\hline & 198 & 6.2 & 28.7 & 22.9 & -5.5 & -6.6 & -0.64 & -6.3 & $71.5^{\star *}$ & -12.7 \\
\hline & 246 & 2.7 & 31.1 & 33.6 & 1.3 & 2.8 & -.7 .6 & 16.2 & $42.7^{\star *}$ & -5.7 \\
\hline \multirow{5}{*}{ 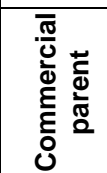 } & 58 & $37.0^{\star *}$ & $111.1^{* *}$ & $107.3^{* \star}$ & -2.7 & $25.6^{\star \star}$ & $59.5^{\star *}$ & 21.2 & $75.7^{\star *}$ & 9.5 \\
\hline & 165 & $59.3^{\star *}$ & $64.4^{\star \star}$ & $69.7^{* *}$ & $2.1^{\star \star}$ & $45.3^{\star \star}$ & $43.7^{\star \star}$ & 50.00 & $30.95^{*}$ & 5.5 \\
\hline & 184 & $5.7^{* \star}$ & $67.4^{\star *}$ & $74.00^{* *}$ & $2.1^{* *}$ & $25.6^{\star \star}$ & $51.4^{* \star}$ & 29.6 & $50.00^{\star *}$ & 6.6 \\
\hline & 198 & 12.96 & $63.2^{* *}$ & $58.5^{\star *}$ & -3.2 & $14.7^{* *}$ & $58.5^{\star *}$ & 7.7 & $70.1^{\star *}$ & 7.3 \\
\hline & 246 & $8.6^{\star *}$ & $66.2^{* *}$ & $72.2^{\star *}$ & $3.1^{* *}$ & $26.7^{\star \star}$ & $47.5^{\star *}$ & 34.6 & $41.6^{\star *}$ & 7.5 \\
\hline
\end{tabular}

${ }^{*}$ and ${ }^{\star *}$ Significant at 0.05 and 0.01 levels of probability, respectively.

Data in Table 9 showed the observed gain as percentage from the better parent and the commercial variety under conventional and late sowing dates for the population II [(Giza75 $\times$ Sea Island) $\times$ Australian13] ranged from 9.00 to $17.60 \%$ and from 30.40 to $40.70 \%$ for seed cotton yield compared to the better parent and the commercial variety, respectively under the conventional sowing date. Also, it ranged from 42.90 to $51.10 \%$ and from 81.20 to $91.50 \%$ for seed cotton yield compared to the better parent and the commercial variety, respectively under the late planting date. .Three best families for lint index differed significantly compared to the better parent under the conventional planting date. Values of the two best families for boll weight, for earliness index and number of bolls/plant were differed significantly compared to the better parent, respectively. One family No. 306 for lint yield as well as seed index the family No. 160 were differed significantly compared to the better parent, respectively under the conventional planting date. 
Table 9: Observed gain and correlated response after one cycle of pedigree selection for seed cotton yield per plant measured in percentage of the better parent and commercial variety respectively in population II under conventional and late planting date.

\begin{tabular}{|c|c|c|c|c|c|c|c|c|c|c|}
\hline \multirow{2}{*}{\multicolumn{2}{|c|}{ Family number }} & \multicolumn{9}{|c|}{ Traits } \\
\hline & & $\begin{array}{l}\text { B.W. } \\
\text { (g) }\end{array}$ & $\begin{array}{l}\text { S.C.Y. } \\
\text { (g) }\end{array}$ & $\begin{array}{l}\text { L.Y. } \\
\text { (g) }\end{array}$ & L.P. & S.I. & E.I. & L.I. & $\begin{array}{l}\text { No. } \\
\text { B./P. }\end{array}$ & $\begin{array}{l}\text { No. } \\
\text { S./B. }\end{array}$ \\
\hline \multicolumn{11}{|c|}{ Conventional planting date } \\
\hline \multirow{5}{*}{ 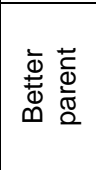 } & 100 & -17.8 & 9.00 & 10.9 & -4.4 & -19.6 & $14.0^{\star \star}$ & -19.3 & $25.1^{*}$ & 2.7 \\
\hline & 160 & $8.6^{*}$ & 16.8 & 24.7 & 1.5 & $16.3^{\star *}$ & -14.2 & $28.8^{\star \star}$ & 7.2 & -8.8 \\
\hline & 203 & $15.13^{\star}$ & 10.5 & 18.8 & 2.00 & 0.00 & 1.7 & $10.5^{*}$ & -4.3 & 10.9 \\
\hline & 215 & 3.3 & 9.9 & 14.9 & -0.50 & -0.98 & $11.8^{\star *}$ & 5.6 & 6.6 & -2.0 \\
\hline & 306 & -1.3 & 17.6 & $27.1^{*}$ & 2.7 & 1.70 & -4.2 & $14.0^{* \star}$ & $19.9^{*}$ & -7.8 \\
\hline \multirow{5}{*}{ 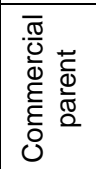 } & 100 & 17.8 & $30.4^{*}$ & 22.9 & -6.7 & -19.6 & $17.3^{\star \star}$ & -28.1 & $50.4^{\star \star}$ & 7.4 \\
\hline & 160 & $8.6^{*}$ & $39.8^{\star \star}$ & $38.4^{\star *}$ & -.0 .98 & $16.3^{\star \star}$ & -11.4 & $14.1^{\star \star}$ & $28.8^{*}$ & -4.6 \\
\hline & 203 & $15.13^{*}$ & $32.2^{*}$ & $31.8^{*}$ & -0.005 & 0.00 & 5.00 & -1.6 & 15.03 & 16 \\
\hline & 215 & 3.3 & $31.5^{*}$ & $27.6^{*}$ & -2.9 & -1.1 & $15.4^{\star \star}$ & -5.9 & $28.1^{*}$ & 6.6 \\
\hline & 306 & -1.3 & $40.7^{\star \star}$ & $41.0^{\star \star}$ & 0.22 & 2.2 & -1.2 & 1.6 & $44.03^{\star *}$ & -3.57 \\
\hline \multicolumn{11}{|c|}{ Late planting date } \\
\hline \multirow{5}{*}{ 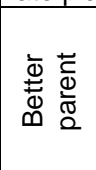 } & 100 & -2.3 & $46.1^{*}$ & $45.4^{*}$ & -0.26 & 0.61 & 15.35 & -0.5 & $52.3^{\star *}$ & -5.6 \\
\hline & 186 & -8.4 & $43.7^{*}$ & $49.8^{\star *}$ & $4.4^{\star \star}$ & 1.4 & 13.00 & $8.2^{*}$ & $59.2^{\star \star}$ & -14.6 \\
\hline & 282 & 5.5 & $42.9^{\star *}$ & $32.8^{*}$ & 2.00 & 10.82 & 16.24 & $13.3^{*}$ & $37.9^{*}$ & -8.4 \\
\hline & 304 & -0.29 & $51.1^{*}$ & $55.0^{\star \star}$ & 2.6 & 9.8 & 15.5 & $13.0^{*}$ & $52.3^{\star \star}$ & -13.00 \\
\hline & 313 & 4.3 & $49.5^{\star}$ & $51.4^{\star *}$ & 1.2 & 8.4 & 16.6 & $10.0^{*}$ & $44.03^{\star \star}$ & -7.2 \\
\hline \multirow{5}{*}{ 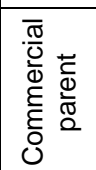 } & 100 & $25.2^{\star \star}$ & $85.2^{\star \star}$ & $87.4^{\star \star}$ & 0.29 & $14.7^{\star *}$ & $50.4^{\star \star}$ & 14.8 & $51.1^{\star *}$ & 7.5 \\
\hline & 186 & $17.4^{\star \star}$ & $82.2^{\star \star}$ & $83.1^{\text {** }}$ & $4.4^{\star \star}$ & $15.1^{\star \star}$ & $47.3^{\star \star}$ & $24.8^{* \star}$ & $57.8^{\star \star}$ & -2.5 \\
\hline & 282 & $35.2^{\star *}$ & $81.2^{\star \star}$ & $87.7^{\star \star}$ & 2.5 & $26.7^{\star *}$ & $51.5^{\star *}$ & $30.8^{* \star}$ & $36.75^{\star \star}$ & 4.6 \\
\hline & 304 & $27.8^{\star \star}$ & $91.5^{\star \star}$ & $99.8^{* \star}$ & $2.8^{*}$ & $25.1^{\star \star}$ & $50.6^{\star \star}$ & $31.5^{\star \star}$ & $51.00^{\star \star}$ & -0.70 \\
\hline & 313 & $33.7^{\star *}$ & $89.5^{\star *}$ & $95.2^{\star *}$ & 1.2 & $23.5^{\star *}$ & $52.02^{\star *}$ & $26.5^{\star \star}$ & $42.8^{\star \star}$ & 5.9 \\
\hline
\end{tabular}

The best five families showed significant difference for seed cotton yield per plant compared to the commercial variety (Giza86) under the conventional planting date. The four best families for lint yield and number of bolls/plant differed significantly compared to the commercial variety, respectively. The two best families exhibited significant difference for boll weight and earliness index. Value of one family for seed index and lint index were differed significantly compared to the commercial variety under the conventional planting date. Concerning the late planting date for population II, the best five families for seed cotton yield, lint yield and number of bolls per plant, were differed significantly compared to the better parent. Also the best four families significantly surpassed for lint index compared to the better parent. Value of only one family No. 186 was differed highly significant for lint percentage compared to the better parent under the late planting date. In comparing with the commercial variety the best five families for boll weight, seed cotton yield, lint yield, seed index, earliness index and number of bolls per plant were highly significant. The best four families for lint index showed significant difference compared to the commercial variety (Giza 86). The best two families for lint percentage significantly surpassed the commercial variety. 
Generally, the previous results showed that some selected genotypes obtained from both populations response to late planting date conditions and achieve economic yield but it late in maturity compared to the better parent. While, these selected genotypes that may be promising at the later generations surpass yielding and more earlier than the commercial variety (Giza 86). These results are in agreement with those obtained by Mahdy (1983 b), Mahdy et al., (1987 a and b), Singh et al., (1993), Awaad and Hassan (1996) and Mahdy et al., (2001 and 2007).

\section{REFERENCES}

Abd El-Salam, M. E. (2005). Studies on breeding and maintenance of cotton varieties G. barbadense L. Ph. D. Thesis, Fac. of Agric., Agron. Dept., Kafrelsheikh, Tanta Univ., Egypt.

Al-Jibouri, H. A.; P. A. Miller and H. F. Robinson (1958). Genotypic and environmental variance and covariance in an Upland cotton cross of interspecific origin. Agron. J., 50: 633-636.

Awaad, H. A. and E. E. Hassan (1996). Gene action, prediction and response to selection for yield and its contributing character in six cotton crosses. Zagazig J. Agric. Res., 23: 217-237.

Badeaa, A. M. M. (2011). Early selection in Egyptian cotton crosses and its response to embryo culture. Ph. D. Thesis, Fac. of Agric., Kafrelsheikh Univ., Egypt.

Burton, G. W. (1952). Quantitative inheritance in grasses $6^{\text {th }}$ Internat. Grassland Cong. Proc., 1: 227-238.

El-Mansy, Y. M. (2005). Using genetic components for predicting new recombinations in some cotton crosses (G. barbadense L.). Ph. D. Thesis, Mansoura Univ., Egypt.

Falconar, D. S. (1981). Introduction to quantitative genetics. $3^{\text {rd }}$ ed., Loingman, New York.

Gamal I. A. Mohamed; S. H. M. Abd-Elhalem and E. M. A. Ibrahim (2009). A Genetic Analysis of Yield and its Components of Egyptian Cotton (Gossypium barbadense L.) Under Divergent Environments. Am-Euras . J. Agric. \& Environ. Sci., 5(1): 5-13.

Hallauer, A. R. and J. B. Miranda (1981). Quantitative genetics in maize breeding . lowa State University press, Ames, USA.

lqbal, M. and M. A. Khan (2011). Response of cotton genotypes to planting date and planting spacing. Front. Agric. China, 5(3): 262-267.

Larsson, K.; K. Ratlite and V. Lilleleht (1997). Heritability of head size in the common gull larus canus in relation to environmental conditions during off spring growth. Heredity, 79: 201-207.

Mahdy, E. E. (1983a). Selection index in cotton (G. barbadense L.). Assiut J. of Agric. Sci., 14: 267-282.

Mahdy, E. E. (1983b). Relative effectiveness of pedigree line and recurrent selection for improving lint yield in cotton ( $G$. barbadense L.). Assiut $\mathrm{J}$. of Agric. Sci., 14: 315-325. 
Mahdy, E. E.; E. A. Hassaballa; M. A. Khalifa and F. G. Younis (1987a). Relative efficiency of three selection procedures in improving yield and its components in Egyptian cotton. Assiut J. of Agric. Sci., 18: 159-175.

Mahdy, E. E.; A. A. Ismail, H. Y. Awad and A. A. Mohamed (2001). The relative merits of breeding and modified recurrent selection in improving seed cotton yield in two segregating populations of Egyptian cotton (G. barbadense L.). The Second Plant Breeding Conf., October 2, 2001: 61-79.

Mahdy, E. E.; A. A. Mohamed; M. Z. Elhifny and H. Mahrous (2007). Selection for seed cotton yield in early and late sowing dates of Egytion cotton. Minia J. of Agric. Res. and Develop., 27(1): 1-22.

Mahdy, E. E.; E. A. Hassaballa; M. A. Khalifa and F. G. Younis (1987b). Comparative studies on three selection procedures in an interasecific population of cotton. Assiut J. of Agric. Sci., 18: 179-195.

Meredith, W. R. and R. R. Bridge (1973). The relationship between $F_{2}$ and selected $F_{3}$ progenies. Crop Sci., 13: 354-356.

Singh, B.; G. S. Chahal and T. H. Singh (1995). Efficiency of different selection criteria for the improvement of seed cotton yield in early segregating generations of (Gossypium hirsutum L.). Crop Improv., 22: 61-64. (C. F. Plant Breeding Abst. 67: 1868-1997).

Singh, M.; V. P. Singh and C. B. Lal (1993). Increase of seed cotton yield through component breeding in short-duration Egyptian cotton (Gossypium barbadense L.). Indian J. Agri. Sci., 63: 639-643.

Singh, M.; V. P. Singh and K. Paul (1985). Selection for yield and quality of (Gossypium hirsutum L.). Indian J. Agri. Sci., 55: 521-525. 
Ali, A. A. et al.

الكفاعة النسبية لبعض التراكيب الوراثية لمحصول القطن و مكوناته تحت مواعيد الزراعة

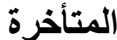

عبد الحميد عبد الحميد على* , علا عبد الرحمن جلال*, محمد عزت عبد السلام*و فتحي

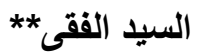

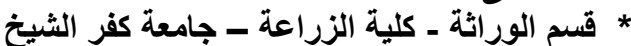

* معهد بحوث القطن - مركز البحوث الزراعية ــ الجيزة

الملخص

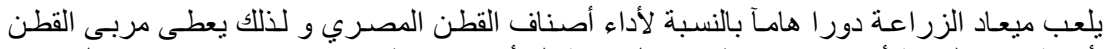

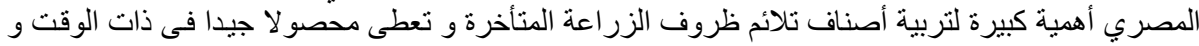

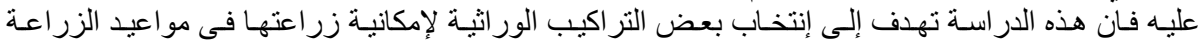

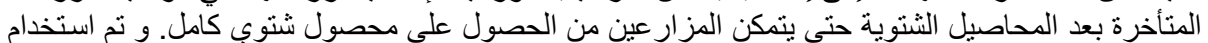

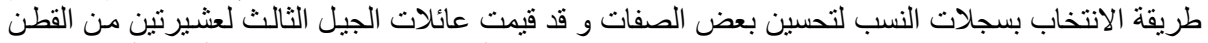

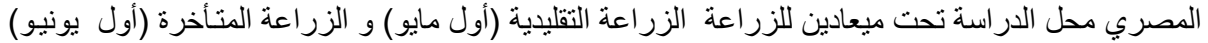

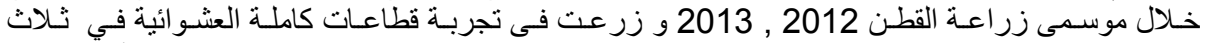

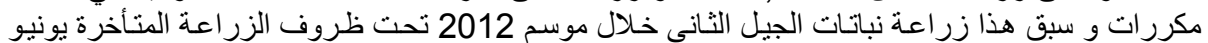

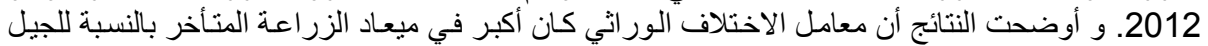

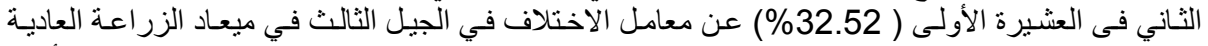

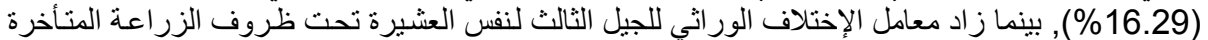

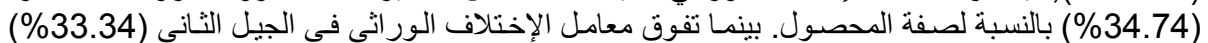

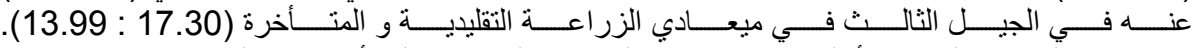

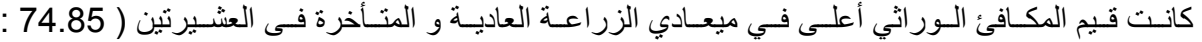

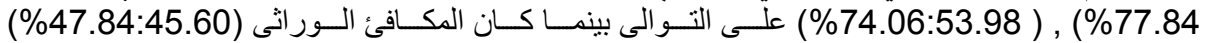

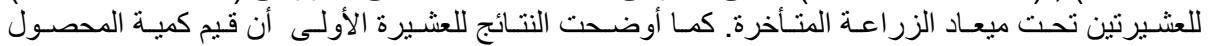

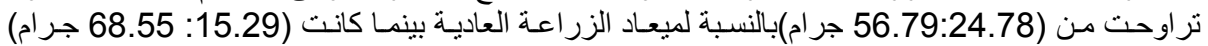
لميعاد الزراعة المتأخرة.

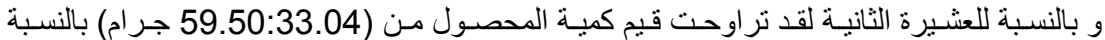

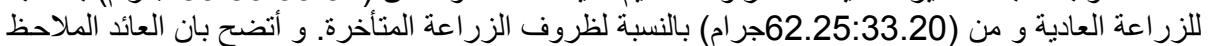

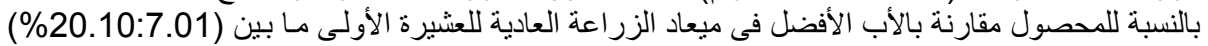

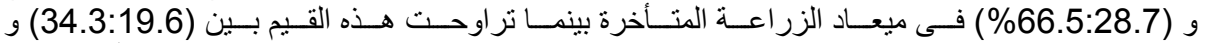

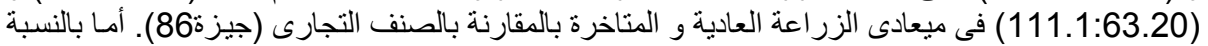

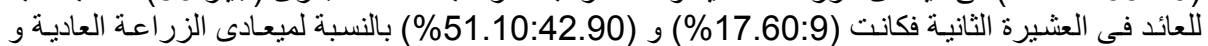

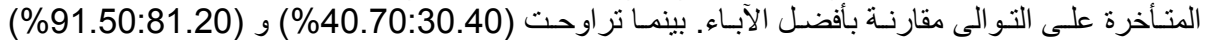

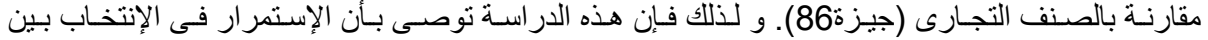

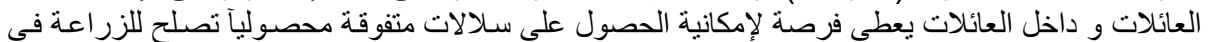

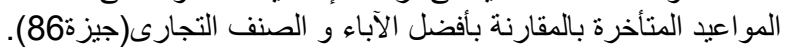


J.Agric.Chem.and Biotechn., Mansoura Univ.Vol. 5 (5): MAy, 2014 

Table 3: Estimates of coefficient variation for genotypic and phenotype variances as well as heritability \% for nine studied traits of the two populations ( $I$ and II) in $F_{2}$ and $F_{3}$ generations, under conventional and late sowing date.

\begin{tabular}{|c|c|c|c|c|c|c|c|c|c|c|c|c|}
\hline \multirow{3}{*}{$\begin{array}{l}\stackrel{0}{0} \\
\stackrel{0}{\frac{0}{\pi}} \\
\frac{\pi}{\Xi} \\
\frac{0}{0}\end{array}$} & \multirow{3}{*}{ 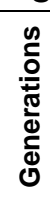 } & \multirow[b]{3}{*}{ 离 } & \multirow[b]{3}{*}{$\begin{array}{c}\text { Parameters } \\
\text { (\%) }\end{array}$} & \multirow{2}{*}{\multicolumn{9}{|c|}{ Traits }} \\
\hline & & & & & & & & & & & & \\
\hline & & & & B.W. (g) & S.C.Y. (g) & $\begin{array}{l}\text { L.Y. } \\
\text { (g) }\end{array}$ & L.P. & S.I. & E.I. & L.I. & No. B./P. & No. S./B. \\
\hline \multirow{9}{*}{ 음 } & \multirow{3}{*}{$\iota^{N}$} & \multirow{3}{*}{ ذّ } & PCV & 16.00 & 47.01 & 48.64 & 10.25 & 10.48 & - & 19.69 & 45.56 & 15.83 \\
\hline & & & GCV & 9.06 & 32.52 & 31.08 & 8.46 & 7.70 & - & 13.57 & 27.65 & 11.37 \\
\hline & & & $h_{b}^{2} \%$ & 32.00 & 47.84 & 40.84 & 68.04 & 54.0 & - & 47.26 & 36.97 & 51.56 \\
\hline & \multirow{6}{*}{$\varphi^{m}$} & \multirow{3}{*}{ 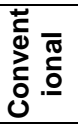 } & PCV & 9.77 & 18.83 & 20.14 & 3.89 & 7.34 & 13.39 & 10.23 & 16.98 & 6.92 \\
\hline & & & GCV & 8.55 & 16.29 & 17.59 & 3.57 & 6.22 & 12.68 & 9.01 & 14.99 & 5.11 \\
\hline & & & $h_{b}^{2} \%$ & 76.60 & 74.85 & 76.30 & 84.03 & 71.96 & 89.62 & 77.67 & 77.91 & 54.62 \\
\hline & & \multirow{3}{*}{ Фّ } & PCV & 9.45 & 39.38 & 38.93 & 3.58 & 8.17 & 13.69 & 9.27 & 27.48 & 7.83 \\
\hline & & & GCV & 7.55 & $34 . .74$ & 34.04 & 3.17 & 7.17 & 12.29 & 7.87 & 24.41 & 6.01 \\
\hline & & & $h_{b}^{2} \%$ & 63.79 & 77.84 & 76.46 & 78.61 & 76.99 & 80.67 & 72.19 & 78.92 & 59.02 \\
\hline \multirow{9}{*}{ 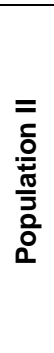 } & \multirow{3}{*}{$\iota^{N}$} & \multirow{3}{*}{ 离 } & PCV & 18.71 & 49.47 & 48.82 & 8.48 & 11.00 & - & 17.42 & 44.32 & 17.93 \\
\hline & & & GCV & 11.28 & 33.34 & 27.83 & 6.44 & 7.40 & - & 9.31 & 19.12 & 13.17 \\
\hline & & & $h_{b}^{2} \%$ & 36.36 & 45.60 & 32.50 & 57.72 & 45.23 & - & 28.57 & 18.19 & 53.93 \\
\hline & \multirow{6}{*}{ एँ } & \multirow{3}{*}{ 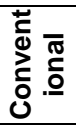 } & PCV & 38.35 & 20.1 & 21.16 & 2.96 & 34.04 & 10.89 & 11.1 & 16.54 & 9.71 \\
\hline & & & GCV & 6.75 & 17.30 & 18.53 & 2.66 & 33.67 & 10.49 & 10.2 & 14.39 & 3.67 \\
\hline & & & $h_{b}^{2} \%$ & 3.10 & 74.06 & 76.60 & 8.65 & 97.8 & 92.8 & 84.67 & 75.7 & 14.35 \\
\hline & & \multirow{3}{*}{ తొ } & PCV & 5.36 & 19.04 & 19.45 & 2.74 & 4.28 & 9.06 & 6.86 & 17.36 & 5.13 \\
\hline & & & GCV & 1.92 & 13.99 & 14.34 & 2.35 & 1.23 & 6.84 & 5.06 & 12.59 & 1.98 \\
\hline & & & $h_{b}^{2} \%$ & 12.90 & 53.98 & 54.37 & 73.50 & 8.28 & 57.03 & 54.40 & 52.60 & 14.90 \\
\hline
\end{tabular}

(-) trait wasn't measured. 
Ali, A. A. et al. 